\title{
From Dominant Perspective to Critical Perspective in Health Communication: Analysis of Turkish Television Health Programs in terms of Critical Health Communication
}

\author{
By Gülhan Gündoğdu*
}

\begin{abstract}
Health communication, which has become a discipline since the mid-twentieth century, has become more crucial especially with the complexness of healthcare applications and health information practices. This has led to an increase in the number of researches and academic studies in the field of health communication and, also different approaches emerged regarding this debate. In order to improve the health of the individual and society, the theories used in the field of health communication are generally limited to individual information and behavior change models. Both the health behavior models, and health communication theory/models used are sociopsychological based approaches. Therefore, the methods used are individually focused. As a result, communication is typically understood as health information transfer and perception. After the changing economic-political approach and public broadcasting replaced by private broadcasting in the 1980s, it's observed that the health communication practices on television started to show an approach towards the consumption of health services and products. This view mentioned above was called 'dominant health communication' in the 1990s and a new approach of the field emerged. Critical approach discusses that health is a social phenomenon and that all responsibility cannot be given to the individual. In this case, outside the individual factors such as economy, politics, culture, environment, education gender and even geography are important in the development and outcomes of health. In this study, it will be discussed that the ongoing health communication practices, which is termed dominant health communication, do not provide a solution to the existing health inequality in the society, on the contrary, they provide the reproduction and dissemination of the ideologies of the sovereign powers and a consent for the consumption of health products and services in the society. Therefore, in this study, health programs on mainstream television channels in Turkey will be analyzed in terms of critical health communication. Critical discourse analysis will be used as the main method of the study.
\end{abstract}

Keywords: critical health communication, dominant health communication, critical discourse analysis, Turkish television health programs

\section{Introduction}

We could emit that, at the beginning, health communication approach which exists in the interpersonal communication universe, is contained more basic information to find solutions to the daily's problems of the individual. Access to all kinds of information has recently made easier with the changing of economics and communications technologies. Health information now reaches itself beyond

${ }^{*} \mathrm{PhD}$ Candidate, Istanbul Commerce University, Turkey. 
the individual's request. Thus, health communication practices done with the media have been moved to a different ground.

It is seen new economics approach affecting the whole world had an impact not only in the economy but also in the healthcare services and media towards the end of the twentieth century. Consequently, the media has been actively used/ being used in the context of the consumption of services and products produced in the field of health. As a result, health communication practices are carried out for individual health problems and demands instead of public health which serve in a more limited area in the meaning of economics.

Although new alternatives are presented to the individual in accessing health information with the latest developments in information and communication technologies (ICTs), television still maintains its influence on a large audience in this field. Television, which is easier to access than other communication tools, is the primary source of certain social segments, especially in the dissemination of health information.

Almost each television channel broadcasted nationally or locally has at least one health program in Turkey. Although these programs are in different formats (edutainment-infotainment, look after yourself), they can reach a significant audience.

Thus, the individual will be able establish an autonomy on own health in order to make decisions with the health information access via television. This causes the misconception that it is more independent in the decision-making process. While it provides advantages to the individual in the field of information asymmetry due to the health communication made on television, it also contributes to a consent production process in the context of the consumption of health services and products.

While the individual is more active than ever in the decision-making process with the health communication applications, on the other hand in the recent years, scholars are getting more and more interested in the field of health communication and different approaches have emerged in the field.

There are also many researches and studies done in Turkey about health communication since the term have emerged. However, it is seen that academic studies are made in the field of public relations, economics and communication technologies, other than communication sciences or sociology of health (Ayaz and Ayaz, 2017). The research methods gathering in socio-cognitive attitudes of individual and ignoring of health is a social phenomenon.

For the reasons aforesaid above, in this paper below assumptions will be analyzed through the language and discourse used in term of critical health communication.

Health communication and practices performed in television health programs:

1. Are completely individual oriented.

2. Ignore social determinants of health such as economic, cultural, and educational.

3. Have no effect in eliminating health inequality in the society. 
4. Play an active role in 'producing consent' in the consumption of health services/products through the discourse of 'healthy living'.

Briefly in this paper it will be discussed, today's changing meaning of the phenomenon of health in the context of critical health communication. Subsequently, the use of television in the dissemination of health information will be explained especially in the context of the Turkish audience. Finally, the persistent television health programs in the mainstream media in Turkey will be analyzed in the context of critical health communication.

\section{The Concept of Health and Health Communication Approaches}

Health as a concept is used in different meanings from society to society and from age to age. It's defined that health as the process of being able to cry, grow old and adapt to the changes in the environment (Illich, 2011, p. 182) or the optimum capacity of the individual fulfilling his/her daily roles and duties (Nordenfelt, 2014).

While the discomfort, whose boundaries are blurred with the discourse made today (Sezgin, 2011) is subjective, the disease is a purely objective and technical term. Health and disease are not an individual phenomenon that exists in humans, but a social phenomenon (Bury, 1997, p. 1).

In the pre-modern period, the concept of health did not appear as much in the everyday discourse of ordinary people as it does today. However, as Baudrillard points out the understanding of health has become a status-related social imperative than a biological imperative in modern time (Baudrillard, 2016, p. 178). Thus, the conditions which were not seen as illness in the first place considered as ordinary situations of daily life or approached by God, are recently defined as diseases (Szasz, 2007, p. 41). Health, illness and disease can be observed not only as a biological and psychological condition, but also as a social condition. In other words, our experiences about health and illnesses are seen to be influenced by the social, economic and cultural characters that the society exists in (Clark, 2010, p. 1).

While it is not easy to figure out where the border between illness and health starts and ends, this situation can be turned into an opportunity today by certain powers such as big-pharma, biotechnology, health industry, etc. (Moynihan and Cassels, 2006; Conrad, 1992). Regarding to neo-liberalism economic-politics approach by the discourse of being healthy (Sezgin, 2011).

Health communication is a concept that emerged in the 1970s in terms of involving the individual in the decision-making process about her/his own health. The main goal of health communication is to influence the behavior of the individual and the society about their health perceptions in the direction of decision-making on their behalf and accomplishing this by sharing health information. Health communication has been described in many ways. The common view of the majority of these definitions is the effective role in the development of health both individual and public health outcomes (Schiavo, 2007; 
Çınarlı, 2008) and, have been used effectively with campaigns to increase public awareness of health problems such as AIDS/HIV, SARS, smoking addiction (Ratzan, 2011). Well-planned health communication practices have positive results both for patients and the society.

The theories used in the dominant health communication approach are limited to individual knowledge, attitude and behavior modification models. The cultural dimensions of health communication are often ignored, and communication in the field of healthcare applications is mostly structured in a top-down manner in paternalist sense (Lupton, 1994, p. 57). Consequently, communication is typically understood as transferring and perceiving health information (Waisbord and Obregon, 2012, pp. 10-13).

In the critical analysis of Dutta-Bergman (2005) for three theories that are widely used in health communication campaigns and which form the dominant cognitive approach, he indicates that the language used ignores the contexts in which communicative meanings are structured. In addition, Dutta-Bergman also states that although different health communication approaches have been developed today, the approaches used so far are systematically structured based on the dominant approach.

Bauman (2014) points out that the reproduction of the conditions of social life is now carried out by things other than collective social tools and, that all its overwhelming pressure is imposed almost directly on the individual. In this sense individuals are their own guide and teacher. In today's discourse the body is indisputably 'private property' and, its care is left to its owner. When considering this approach of Bauman, it could be concluded that the theories/models commonly used in dominant health communication support this approach.

Deborah Lupton explains in her article (Lupton, 1994), which is one of the pioneering study about critical health communication perspective focusing on critical health communication, that the content of dominant health communication is traditionally done by a top-down manner that flows from the central authority to the periphery. Critical perspective structures health communication as a political process and draws attention to the power relations that determine the relations between classes in society. It identifies the communication as 'the ability to shape social context' and, argues that power is at the center of defining problems and solutions (Dutta, 2010). Consequently, ignores social problems and inequality which exist in the society.

Health communication practices done recently have moved away from addressing considerably public health issues (Depp, 2011, pp. 16-25) and, become more individualized. At the same time, it is seen that today's health policies and services have transformed from the understanding of conducting a collective struggle against social risk to an understanding of supporting capital accumulation. The ongoing health communication, which is structured on the discourse of 'being healthy' works towards producing consent in the consumption of health services and products. As a result of this it raised the question of whether health is a right or a commodity. 


\section{Dissemination of Health Information and Television}

Healthcare and services have recently become more widespread and complex. In the face of this increasing information and variety of services put the individual in a more passive position than active contrary to expectations. Besides many topics, current information in the field of health is also now accessible via media tools. As such, access to health information and health communication practices gain more importance. The media are used effectively by the public-private sector and NGOs in health communications and applications. However, these activities, especially by the private sector, are carried out within the framework of the marketing approach of the institution.

Although the media have many advantages for informing the public, the source and content of the information provided can function in favor of power focuses that hold the apparatus, not in favor of the individual. The 1980s, when neoliberalism emerged, witnessed a radical transformation of the media industry. Especially with the tendency of television from public broadcasting to private broadcasting since the 1980s (Adakl1, 2010), the conglomeration of media organizations has brought these discussions at the center of media studies.

Mass media has the potential to significantly or negatively alter how healthrelated information is spread and received by different populations (De Jesus, 2013, p. 525). Although the media marginalizes certain ideas and keeps them out of the agenda (especially the political, economics causes of diseases), it still plays an active role in creating agenda about health and disease in the public (Karpf, 1988, p. 2; Dutta, 2007). The discovery and spread of the internet and developments in information and communication technologies (ICTs) have decreased the effectiveness of traditional media in this field. But television is still actively used in dissemination of health information. The audience can access health information both through the health programs broadcast during the daytime and the television series broadcast in prime time. While these contents entertain the audience, they can raise awareness by drawing attention to the health problems (Brodie et al., 2001; Murphy et al., 2008).

Announcing a health problem to the public, adopting a desired health behavior to large masses is possible with the campaigns to be carried out through mass media (Bulduklu and Koçak, 2010, p. 73). In particular, television is the most effective tolls used in this field. Television is actively used by both government and non-governmental organizations in health-related campaigns such as the importance of physical activity for health, substance abuse, communicable diseases, AIDS. In fact, if the subject is not put on the agenda of the television sufficiently, caused the opinion that it does not have the necessary effect on the public (Turow and Coe, 1993, p. 130).

Television is an important source of information about health and, it is also the medium where both positive and negative health-related messages paradoxically exist. Television health perspective is biomedical approach and, diseases are treated with drugs or machines (Çınarl1, 2019, p. 153). Television produces an understanding that disregards or mitigates the most important determinants of health such as social, economic and political factors. 
In television health programs where healthcare professionals, mostly physicians, are hosted and, disease, cutting-edge treatment methods are discussed. Although the format and discourse change according to the broadcast time and the targeted audience of the television channel, the content generally remains the same. Anne Karpf addresses health programs broadcasted on television in four main approaches (Karpf, 1988). Although these four approaches do not have definite limits, they are common in today's media culture. These are the medical approach, the consumer approach, the look after yourself approach and the environmental approach.

\section{Research Methodology}

Critical discourse analysis (CDA) see 'language as social practice' and consider the 'context of language use' to be crucial (Wodak and Meyer, 2016). In the study, within the scope of critical discourse analysis method, how the relations of power are structured in discourse will be analyzed. In this context, by using Norman Fairclough's dialectical rational approach method will be used to analyze the words, concepts and body language used by the healthcare professionals namely the actors, while performing the social action in the context of ideology.

As we know the critical approach of CDA characterizes scholars rather than their methods. CDA scholars and their researches are socio-politically committed to social equality and justice. They are specifically interested in the discursive production/reproduction of power abuse and the resistance against such domination. CDA is more problem-oriented than discipline oriented (Van Dijk, 2016, p. 63).

Critical discourse analysis sees the language used in speaking and writing as a form of social actions. Defining special discourse as a social practice implies a dialectical relationship between a discursive action and situations, institutions and social structure. Critical discourse analysis focuses on the analysis of recognizing powers implicit/explicit, concealed, blurring visible sovereign structures with the use of language (Wodak and Meyer, 2016, pp. 6-12).

In the research health programs broadcasted in the mainstream media channels in Turkey will be analyzed. HT Sağlık (HT Health)-Haber Türk Channel and Sağlık Kontrolü (Health Check)-CnnTürk Channel. Both are the longest running television programs about health issue in Turkey. The program's analysis is limited to six months of 2018 which are April, May, June, October, November and December and contains 49 episodes. Health Check Program includes 24 episodes. Each episode takes about 44-47 minutes and HT Health Program includes 25 episodes. Each episode takes an average of 22-25 minutes. In the study television health programs analyzed in line with the assumptions of the research. The analysis that includes a qualitative research method includes: Branches and occupational diversity of health professionals participating in the programs. Sector representations of the participating guests; public and private sector. The way discussing health problems and health promotion. The content of solution's 
suggestions and approaches; preventive health services, diagnostic/therapeutic services and, language, images used in the programs.

The reasons to choose these specific 6 months period are:

The first reason is the broadcasting period of the programs and the second reason is seasonal reasons. Which means;

These months indicate seasonal transitions. In the autumn, flu is always on the agenda. Furthermore, the autumn is a common occurrence in communicable diseases and digestive infections due to water pollution and air pollution. For children it's time for returning to school, millions of children are involved in crowded environments at the same time. These are the months when both climate change and related diseases and human mobility are most intense. In short, my aim is to observe that real-time health problems especially public health problems and the topics covered in these programs overlap or not.

Furthermore, preferring television for the research universe is related with Turkish sociological infrastructure. Turkish people still mostly trust television as a source of information (69.2\%) and television viewing rate is $86.7 \%$ (RTÜK, 2018). This ratio gets higher for older people (probably suffering at least one chronic disease). In access to health information in Turkey, television is in the first place. These programs target female audience while women are responsible for the health of the family in Turkey. Everything is all there; there are health professionals or celebrated doctors. This is the general view of the Turkish audience.

In addition to, Turkey health literacy researches show that only one in three people have an 'adequate health literacy' (SES Sendikası, 2014; Turkish Health Ministry, 2018) To sum up for all these reasons listed above, television will be a reasonable field of study.

\section{Analysis of Turkish Television Health Programs in Term of Critical Health Communication}

The study aims to analyze television health programs' content. Branches and occupational diversity of health professionals participating in the programs. Sector representations of the participating guests; public or private. The way discussing health problems and health promotion. The content of solution's suggestions and approaches; preventive health services, diagnostic/therapeutic services and, language, images used in the programs.

Critical discourse analysis sees language as a means of social action. It argues that power and hegemony are structured by the language. In the study, the dialectical rational approach method was used to explain how those who have power in the field of health (health professionals, big pharma, medical technology) use language in order to build and maintain their hegemony in the health communication practices on television. This approach analyzes not only languagestructured discourse, but also body language. Accordingly, in the study, besides the language used in the program, the guests' body language is also analyzed.

In the 49 analyzed episodes, among the 108 participating specialists, only 5 guests are in the field of internal medicine and, there is no public health specialists. 
Only 16 of the participating expert guests are in the public sector, while the remaining 92 represents the private health sector. In the programs advanced medical technology and new treatment methods are introduced or discussed rather than public health problems and solutions. Almost all the guests attending are physicians. Both the side effects of treatment and social security coverage are mitigated or keep out of agenda. Title of institutions represented by the guests participating in the program are clearly published.

\section{Power Discourse}

The power over health is completely in the hands of physicians in the programs and, constantly physicians are hosted to talk about disease and health (Table 1). Thus, the health discourse is under the control of 'biomedical discourse'. Most of the experts participating in the programs are in the field of surgical sciences (Table 2).

Table 1. Proportion of Participants

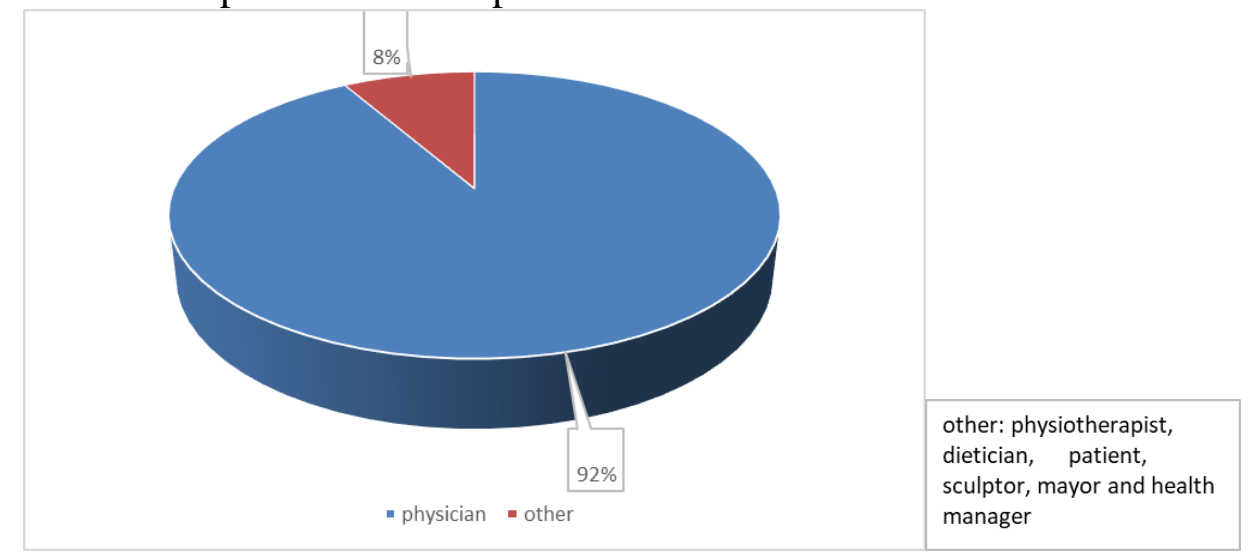

Table 2. Most Attended Branches

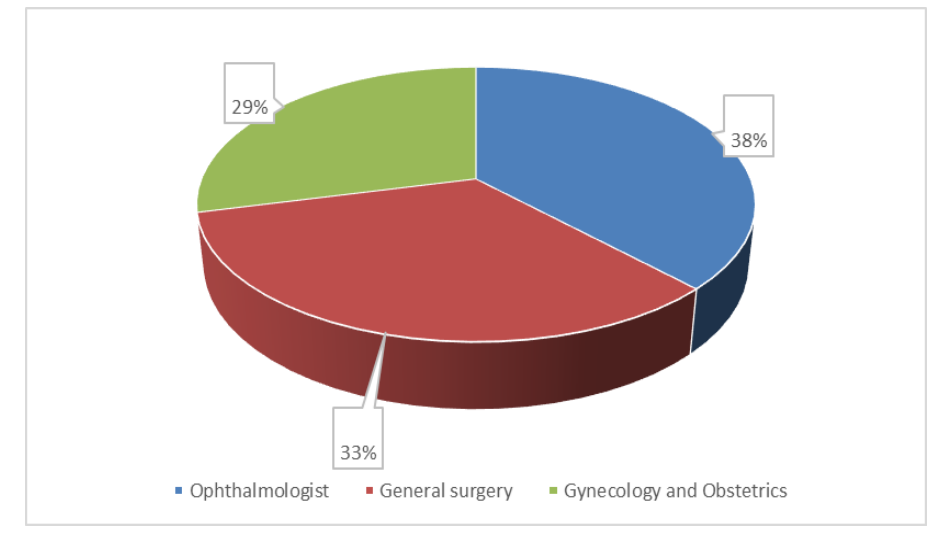

Given information is generally about new advanced treatment methods and medical technology. Surgical method is presented as the 'single solution' for health problems. Such as zygomatic implants, stomach reduction surgery, robotic 
surgery, surgery solution to obesity, new generation eye surgeries, new generation lenses and new developments in IVF treatment. These contents are constantly being repeated in the programs.

The power established on health information is under the control of physicians with this discourse. As a result of this sovereignty of physicians, it is ignored that health is a social phenomenon in terms of body, spiritual and social aspects.

\section{Re/production of Power in the Context of Language Use}

Fairclough defines facial expressions, body language which is visual elements of speech language, in discourse analysis (Fairclough, 2015, p. 125).

All guests participating in these programs are extremely stylish and they wear suits. They are not wearing white coats and do not have a stethoscope. The guest sitting on the sofa, leaning back gives a confident, dominant impression. As if saying 'yes I am here but it is not that much easy to reach to me'. The ongoing conversation between the announcer and the guest gives the impression as if there was no audience. The participants do not look directly at the camera, they look at each other. Sometimes guests sit opposite each other with the presenter or stand up against each other. But there is always a certain distance between them (Figures 12).

Figure 1.The Participant and Presenter Position in the Program

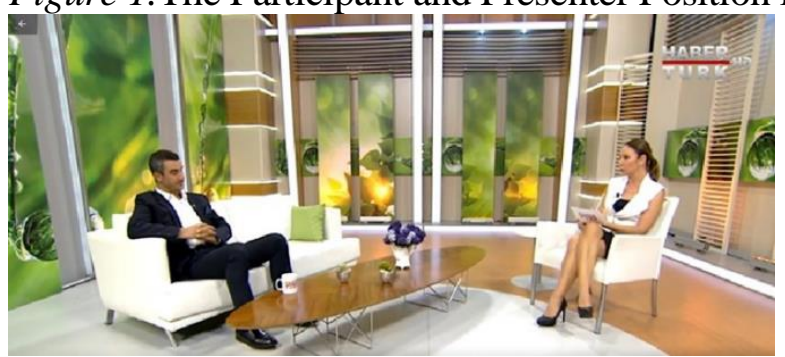

Source: https://www.youtube.com/watch?v=IAuaxY9Ft9M 2nd June 2018 HT Health Program/ Haber Türk Channel

Figure 2. The Participant and Presenter Position in the Program

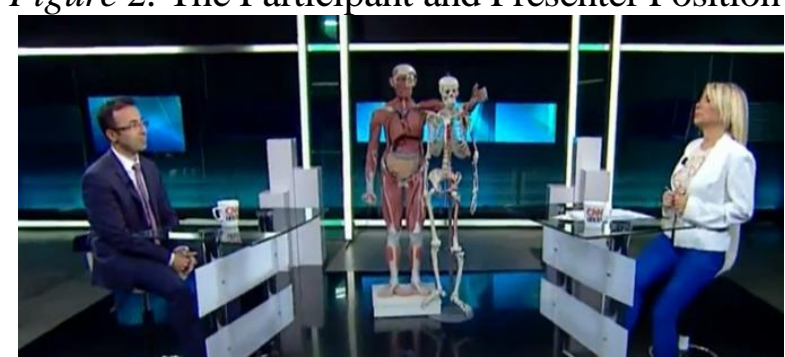

Source: https://www.youtube.com/watch?v=zTE6jwvp51k 24 November 2018 Health Check Program / CnnTürk Channel.

In the programs, while explaining the method of treatment the guest uses a model and goes into a lot of details and terminology, as if she/he is lecturing medical students in amphitheater (Figure 3). 
Figure 3. The Use of Model in the Program

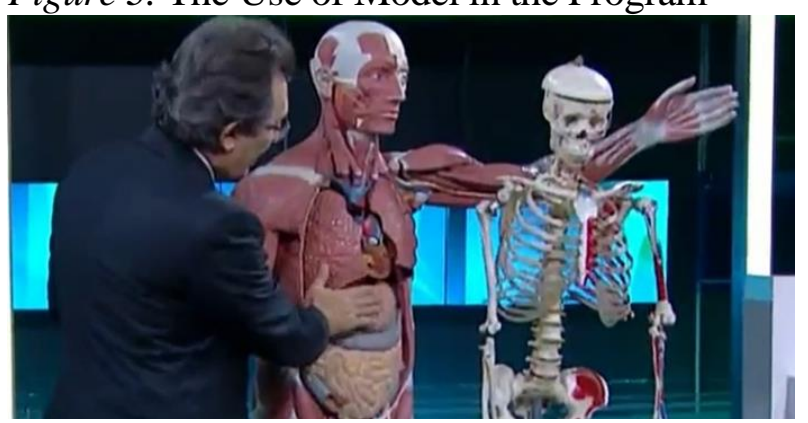

Source: https://www.youtube.com/watch?v=QovcHgfJHys 21st April 2018 Health Check Program / CnnTürk Channel

The announcer is constantly referring to the expert guests as "professor" (Hocam) not by her or his name. This is an important use of language in Turkey recognizing of authority.

\section{Ignoring the Social Determinations of Health and Putting the Responsibility on the Individual}

While explaining the disease and its causes social determinants of health are mostly ignored. Especially, while explaining the common health problems such as obesity and COPD (Chronic Obstructive Pulmonary Disease) all responsibility is given to the individual. It is also repeated constantly that the only cause of COPD is smoking. The given perception is that if an individual gives up smoking, there will be no COPD. Environmental pollution caused by the over production of the industry or coal power plants (Gümüşel, 2015 ) are not mentioned.

"We know the reason is smoking".

"...smoking in most people, air pollution in some" (Karakoca, 2018).

Even though the specialist physician who emphasized that COPD disease increases in winter has linked the cause to individual cases, not to environmental pollution. Smokers are always the responsible, not insufficient health services, for patients who could not be hospitalized and lost their lives. Because there was no vacant bed, because of COPD's patients.

"...in the first place in hospital occupation" (Karakoca, 2018).

"COPD comes from preventable diseases if smoking is stopped" (Karakoca, 2018).

Environmental pollution and stress factors due to overproduction are ignored or mitigated. About obesity disease treatment only surgical methods are discussed in all of 49 episodes analyzed.

"Obesity surgeries became popular" (representor).

"These surgeries prevent cancer and prolong life by ten years".

"... You will do this surgery to get rid of death" (Türkçapar, 2018). 
All guests participating in the programs about obesity disease are in the surgical branch. A perception is created as if obesity disease can heal only by surgical methods. There is no real cause of obesity disease. Specialist guests participating throughout the programs never mentioned that: Fast-foods are cheaper and easier to access than natural foods, economic and social barriers to healthy and balanced nutrition and food additives (WHO, 2020). All experts participating in the program are the best in their field. If a problem occurs in the treatment, the physician is not responsible for this.

"The patient... must believe" (because he/she didn't believe enough to the treatment).

"... a little bit of unluck".

"...this is fortune" (Gürbüz, 2018).

Talking about knee and joint prosthesis operations, the physician puts all the responsibility on the patient after the operation occurring problems. No matter the participant represents public or private health sector.

Communication is made with an approach that does not see the socio-cultural and economic factors of the society or is completely excluded. It is frequently repeated that most of the health problems are caused by our personal mistakes. It alienates the audience by creating the perception that the audience does not listen to the physician.

"...not consuming healthy food..." "... does not do sports..." (Demirsoy, 2018).

"Turkish society is not a society that loves exercise" (Şeber, 2018).

Although individual lifestyle factors such as smoking, exercise and nutrition are cited as the main cause of health problems, the main factors of inequality in the society should not be seen separately from the socio-economic environment (Shaw et al., 2009, p. 231).

\section{Production of Consent in the Context of Language Use}

All the expert guests participating in the programs are given the impression that they are the best in their own field. The program presenter introduces the guest in such announcements.

"An important, expert, experienced physician in his /her own field..."

"We chose the best and most specialized physician".

By presenting expert guest in this way; the perception that every treatment and method he will say is indisputably correct and fixed with his experience shows that he/she is accepted by the media authority from the very beginning of the program. In the discourse, the perception that the information given in the field of health is thus the most recent and acceptably the best.

"I came to your hospital, I saw, there is a very strong team" (presenter, Health Check). 
Moreover, while this discourse is being created, the presenter as an actor of the discourse firstly proves the situation on her behalf.

Participating guests also use the 'I language' which supports the content of the program as a scientific authority and gives the impression that he/she is a dominant power over the treatment methods. Establishing authority over knowledge in the context of the discourse of I language such as.

"I'm the first doctor to realize this, in the World".

"I did the intra-bronchial cleaning".

"I was the first to apply obesity surgery".

While talking about the treatment methods, the participating specialist widely uses the 'language of fear'. The physician creates a discourse by exaggerating, dramatizing and using metaphors.

"...cause to deadly disease, if..."

"...not a cosmetic problem" (Barlas, 2018).

The specialist giving information about varicose vein diseases, producing consent by warning audience "...is more serious than cosmetic".

While participants describe the disease, they commonly use metaphors in examples in the production of meaning. Expressing that the body is objectified with the process of capitalism and Foucault also says that one of the process of bio-power is the mechanization of the body (Foucault, 2006, p. 63; Toplum ve Bilim Dergisi, 2011).

"...given generally an example... one changes car's oil filter, gas filter or everything of one's car so often... but when the hormones of one is diminished, I should put them back, should adjust the doses again... 1 should get my youth levels... unfortunately there is no effort in this way" (Aytekin, 2018).

With this discourse, the physician explains that old age is not a process of life, but a pathological condition and, creates the perception that it can reverse the life cycle with hormone replacement.

New disease concepts are produced in the program such as undiagnosed diseases. The term of undiagnosed disease is actually the condition in which the physician has not enough time for the patient because of work burden. Moreover, it is the output of poor health policies. In a system where a physician examines an average of 100-150 patients per day (Çamsarı, 2013). The physician will not be able to devote enough attention and time to the patient. As a result, this will cause either delay or misdiagnosis in the diagnosis. Through the inequality applications of the neoliberal system's undiagnosed diseases will arise and create a new market area. Increasing the visibility of health professionals in the media; it is the visible democratization of the discourse that involves the reduction of the clear indicators of the power asymmetry between physician and patients who are individuals of unequal institutional power. Dissemination of health information through television health programs is an example of that. For example: The fact that physicians 
participating in these programs seem comfortable and openly responding to every question, causes the illusion of 'there is no access problem' in the audience side. This tendency can be interpreted as not the destruction of the power asymmetry but its transformation into unseen forms (Fairclough, 2015, p. 131). Thus, consent is produced in the society without being forced through discursive democratization. In other words, the problems that result in the realization of the physician-patient relationship are entirely because the patient cannot define the correct question or problem communicatively. The use of widely occupational jargon and, giving unnecessary details about the disease and treatment create confusion, rather than informing the audience.

\section{Conclusion}

Althusser counts mass media among the ideological apparatus of the state in which the state ideology is maintained. Unlike repressive state apparatuses the ideological apparatuses of the state take place in the private sphere and, they establish their hegemony by producing consent without pressure. It works as an ideological apparatus for the production and maintenance of capitalist production relations in the media. While doing this, it adds uniqueness to the individual and makes it subjective and, structures its discourse directly by addressing the individual, calls or names individuals as subjects (Althusser, 2002). Health communication discourse made by offering personalized options with the concepts of 'personalized medicine', 'personalized treatment method' is also an ideological approach addressing the subject individually. The message and action given in health communication with media are ideological. Although it creates a perception as if there is a subject in the discourse, it is an effort for the marketing of the products/services in the subtext.

In addition to while explaining health problems and treatment methods in the programs, a language consisting of medical terms and concepts is used instead of a simple language that the individual can understand. Simple health problems are explained with a statement that "if not treated in time, it will be fatal". Using incomprehensible words followed by metaphors in discourse could be cause confusion in the audience. The side effects of the treatments are not mentioned and, the procedure is conveyed as if it was very simple. If there is a problem during the treatment process the patient is responsible for not listening properly and doing what is said.

In the programs diagnosis and treatment methods are mostly described. The factors which are the main source of the diseases are not taken into the agenda. The causes of the diseases are explained more superficially, depending on individual behavior and attitudes. As a result, the main factors outside the individual's access will never come to the consideration. In the communication, the main responsible of this whole process is excluded from the discourse. Health communication through television is structured within the framework of biopower, evidence-based medicine discourse. 
The constant presence of physicians in the programs creates the impression in the audience that only the physicians 'have a say' in the field of health. Looking at the holistic, representatives of other areas of expertise, decision makers and policy makers that have a direct or indirect impact on health should also be included in these programs. Health which has economic, cultural, environmental and political aspects, is naturally within the responsibility of the individual since it is not spoken in this context.

Inspired by the concept of Beck (2011), health problems are a phenomenon with boomerang effects, especially in the public health. Since decision-makers and other representatives of the health sector are not represented in the programs and, access to treatment methods and social security coverage are not mentioned in this respect the conclusion could be drawn that the audience is not sufficiently informed about healthcare.

As long as the television is the primary source to access to health information for the community with insufficient health literacy such as Turkey, the television health programs content becomes more important. In line with this analysis, television health programs should be structured with a concept in which all stakeholders of the issue should be represented regarding the basic health of the individual and society, including public health practices and policies. Constructing health communication and practices within the framework of public broadcasting principle will also have a positive effect on the development of health communication in the society.

Otherwise, if access to health information is left only to private television broadcasting in the society, the implementation will be inevitably aimed at the promotion and marketing of the private health sector rather than the awareness of health communication in the society.

\section{References}

Adaklı, G. (2010). Neoliberalizm ve medya: dünyada ve Türkiye'de medya endüstrisinin dönüşümü. (Neoliberalism and the media: the transformation of media industry in the world and Turkey). Mülkiye, 34(269), 67-84.

Althusser, L. (2002). İdeoloji ve devletin ideolojik aygitlart. (Ideology and ideological state apparatuses). $5^{\text {th }}$ Edition. Translated by Y. Alp, M. Özışı. İstanbul: İletişim Yayınları.

Ayaz, F., Ayaz, H. (2017). Sağllk iletişimi ve medyayı konu alan lisansüstü tezlere yönelik bir analiz. (The analysis of health communication and media related researches between 1988-2017). Atatürk İletişim Dergisi, 147-172.

Aytekin, A. F. (2018). HT sağlı. (HT health). (C. Erenoğlu, Presenter). İstanbul: HaberTürk Channel.

Barlas, S. (2018). HT sağllk. (HT health). (C. Erenoğlu, Presenter). İstanbul: HaberTürk Channel.

Baudrillard, J. (2016). Tüketim toplumu. (The consumer society). $8^{\text {th }}$ Edition. Translated by H. Deliçaylı, F. Keskin. İstanbul: Ayrıntı Yayınları.

Bauman, Z. (2014). Parçalanmış hayat- postmodern ahlak denemeleri. (Life in fragments and essays in postmodern morality). $1^{\text {st }}$ Edition. Translated by İ. Türkmen. İstanbul: Ayrintı Yayınları.

Beck, U. (2011). Risk toplumu. (Risk modernity: towards a new modernity). $2^{\text {nd }}$ Edition. Translated by K. Özdoğan, B. Doğan. İstanbul: İthaki Yayınları. 
Brodie, M., Foehr, U., Rideout, V., Bear, N., Miller, C., Flournoy, F., et al. (2001). Communicating health information through the entertainment media. Health Affairs, 20(1), 192-199.

Bulduklu, Y., Koçak, A. (2010). Sağllk iletişimi. (Health communication). 1st Edition. İstanbul: Akademi Basın.

Bury, M. (1997). Health and illness in a changing society. $1^{\text {st }}$ Edition. London \& New York: Routledge.

Çamsarı, U. M. (2013). Bir hekim günde kaç hasta bakabilir? (How many patients a day can a physician examine?) Retrieved from: https://www.medimagazin.com.tr/guncel /genel/tr-bir-hekim-gunde-kac-hasta-bakabilir-11-681-54189.html. [Accessed 25 May 2020.]

Çınarlı, İ. (2008). Sağglı iletişsimi ve medya. (Health communication and media). $1^{\text {st }}$ Edition. Ankara: Yordam.

Çınarlı, İ. (2019). 21. yüzyıl için sağlık iletişimi. (Health communication for the $21^{\text {st }}$ century). $1^{\text {st }}$ Edition. İstanbul: Nobel Kitapevi.

Clark, A. (2010). The sociology of healthcare. $2^{\text {nd }}$ Edition. London: Pearson Education Limited.

Conrad, P. (1992). Medicalization and social control. Annual Review of Sociology, 18(Aug), 209-232.

De Jesus, M. (2013). The impact of mass media health communication on health decisionmaking and medical advice-seeking behavior of U.S. Hispanic population. Health Communication, 28(5), 525-529.

Demirsoy, E. (2018). HT sağllk. (HT health). (C. Erenoğlu, Presenter). İstanbul: Haber Türk Channel.

Depp, U. H. (2011). Sağllk hizmetlerinin doğası: metalaştırmaya karşı dayanışma. (The nature of healthcare: solidarity against commodification). In L. Panitch, C. Leys (eds.), Kapitalizmde Sağlık Sağlıksızlı Semptomları. Translated by Y. Kitap. $2^{\text {nd }}$ Edition. İstanbul: Yordam.

Dutta, M. J. (2007). Health information processing from television: the role of health orientation. Health Communication, 2l(1), 1-9.

Dutta, M. J. (2010). The critical cultural turn in health communication: reflexivity, solidarity, and praxis. Health Communicaiton, 25(6-7): 534-539.

Dutta-Bergman, M. J. (2005). Theory and practice in health commınication campaigns: a critical interrogation. Health Communication, 18(2), 103-122.

Fairclough, N. (2015). Söylemin diyalektiği. (Dialectic of discourse). In B. Çoban, Z. Özarslan (eds.), Söylem ve İdeoloji, 137-146. Translated by B. Çoban, Z. Özarslan, N. Ateş, A. E. Pilgar. $2^{\text {nd }}$ Edition. İstanbul: Su Yayınları.

Foucault, M. (2006). Hapishanenin doğuşu. (Discipline and punishment). $3^{\text {rd }}$ Edition. Translated by M. A. Kılıçbay. Ankara: İmge Yayınevi.

Gümüşel, D. (2015). Ödenmeyen sağllk faturasl: Türkiye'de kömürlü termik santralleri bizi nasil hasta ediyor? (The unpaid health bill: how coal power plants make us sick in Turkey). HEAL - Health and Environment Alliance.

Gürbüz, H. (2018). Sağllk Kontrolü. (Health check). (L. Ataman, Presenter) İstanbul: CnnTürk Channel. Retrieved from: https://www.youtube.com/watch?v=sRUrcnvf5 KQ. [Accessed 15 February 2020.]

Illich, I. (2011). Sağlı̆̆ın gaspı. (Limits to medicine nemesis: the ecpropriation of health). $2^{\text {nd }}$ Edition. Translated by S. Sertabiboğlu. İstanbul: Ayrıntı Yayınları.

Karakoca, Y. (2018). HT health. (C. Erenoğlu, Presenter) İstanbul: HaberTürk Channel. Retrieved from: https://www.youtube.com/watch? $=\mathrm{Cx} 4 \mathrm{Sx} 1 \mathrm{ShinY}$. [Accessed 7 February 2020.] 
Karpf, A. (1988). Doctoring the media: the reporting of health and medicine. $1^{\text {st }}$ Edition. London: Routledge.

Lupton, D. (1994). Toward the development of critical health communication praxis. Health Communication, 6(1), 55-67.

Moynihan, R., Cassels, A. (2006). Satılık hastalıklar. (Selling sickness). $1^{\text {st }}$ Edition. Translated by G. Tamer, E. Yıldırım. İstanbul: Hayykitap.

Murphy, S. T., Hether, H. J., Rideout, V. (2008). How healthy is prime time? An Analysis of health content in popular prime time television programs. Hollywood: The Kaiser Family Center \& The USC Annenberg Norman Lear Center's.

Nordenfelt, L. (2014). On the notion of health as ability. Scandinavian Journal of Occupational Therapy, 21(Sup.1), 48-52.

Ratzan, S. C. (2011). Health communication: beyond recognition to impact. Journal of Health Communication, 16(2), 109-111.

RTÜK - Turkish Radio and Television of Supreme Council (2018). Televizyon izleme eğilimleri araştırmast. (The research of television audience trends). RTÜK.

Schiavo, R. (2007). Health communication - From theory to practice. $1^{\text {st }}$ Edition. San Fransisco: Josssey-Bass.

Şeber, G. (2018). HT sağglk. (HT health). (C. Erenoğlu, Presenter) İstanbul: HaberTürk Channel.

SES Sendikası (2014). Türkiye sağlık okuryazarlı̆̆ı araştırması. (Turkish health literacy research). SES Sendikası.

Sezgin, D. (2011). Tibbileștirilen yaşam bireyselleştirilen sağlık. (The medicalization of life and individualised health). ${ }^{\text {st }}$ Edition. İstanbul: Ayrıntı Yayınları

Shaw, M., Dorling, D., Smith, G. D. (2009). Yoksulluk, toplumsal dışlanma ve azınlıklar. (Poverty, social exclusion and, minority inside). In M. Marmot, R. G. Wilkinson, B. Adiloğlu, C. Ergül, N. Erten, İ. Kayı et al. (eds.), Sağlığın Sosyal Belirleyicileri. $1^{\text {st }}$ Edition. İstanbul: İnsev

Szasz, T. (2007). The medicalization of everyday life-selected assay. $1^{\text {st }}$ Edition. Syracuse University Press.

Toplum ve Bilim Dergisi (2011). Biyoiktidar-Biyopolitika. (Bioactider-Biopolitica). Toplum ve Bilim Dergisi (122/ Özel sayı).

Türkçapar, A. (2018). HT sağllk. HT health. (C. Erenoğlu, Presenter) İstanbul: HaberTrük Channel. Retrieved from: https://www.youtube.com/watch?v=yUeinF3bhPc. [Accessed 7 February 2020.]

Turkish Health Ministry (2018). Türkiye sağglk okuryazarlığı düzeyi ve ilişkili faktörleri araştırmast. (Turkey health literacy levels and related factors research). Turkish Health Ministry.

Turow, J., Coe, L. (1993). Curing television's ills the portrayal of health care. In B. C. Thorton, G. L. Kreps (eds.), Perspectives on Health Communication. Waveland Press Inc.

Van Dijk, T. A. (2016). Critical discourse studies: a sociocognitive approach. In R. Wodak, M. Meyer (eds.), Methods of Critical Discourse Studies, 62-85. London: SAGE.

Waisbord, S., Obregon, R. (2012). Theoritical divides and convergence in global health communication. In R. Obregon, S. Waisbord (eds.), The Handbook of Global Health Communication, 8-33. John Wiiley \& Sons.

WHO (2020). Obesity and its roots. Retrieved from: https://www.who.int/news-room/ev ents/detail/2020/03/04/default-calendar/world-obesity-day. [Accessed 22 September 2020.]

Wodak, R., Meyer, M. (2016). Critical discourse studies: history, agenda, theory and methodology. In R. Wodak, M. Meyer (eds.), Methods of Critical Discourse Studies. $3^{\text {rd }}$ Edition. London: SAGE. 